\title{
Conservation status of the genus Hampea (Malvaceae: Gossypieae) in Mexico
}

\author{
Robert W. Jones*, M. Fernanda Cruz-Torres, Carlos López-González, \\ and Magdalena A. Duarte-Fernández
}

Botanical Sciences

96 (3): 426-442, 2018

DOI: $10.17129 /$ botsci.1857

Received:

August 28th, 2017

Accepted:

April 26th, 2018

Associated editor:

Salvador Arias
Facultad de Ciencias

Naturales, Universidad Autónoma de Querétaro, Juriquilla, Querétaro, México. *Corresponding author: rjones@uaq.mx.

Authors Contributions:

R. W. Jones, writing, analysis of MER criteria, field work and specimen examination; F. Cruz-Torres, modeling of potenctial distribution, C. López-González, Mer criteria and editing; M. DuarteFernández, compilation of data base.

This is an open access article distributed under the terms of the Creative Commons Attribution License CC BY-NC (4.0) international.

\section{Abstract}

Background. The genus Hampea (Malvaceae: Gossypieae) has 21 reported species and occurs in Mexico, Central America and Colombia. Mexico has eleven species, of which seven are endemic. Hampea is of special conservation interest because its members are wild relatives of cultivated cotton and several species are apparently threatened by anthropogenic activities.

Questions. What is the conservation status of species of Hampea in Mexico?

Study site and years of study. Observations were made in the field during 1991-1995, 2012 and 2016 in southern Mexico. Specimen data was obtained from the CONABIO data base and from national and international herbaria from 2014-2016.

Methods. The conservation status of species of Hampea in Mexico was evaluated using criteria given in the Methods of the Evaluation of Risk of Extinction of Plants (MER-Plantas) (NOM-059-SEMARNAT2010). The potential distribution was calculated using Maximum Entropy Algorithm and biological data for species were obtained from literature and field observations.

Results. Seven species of the genus Hampea were considered to be in a category of risk under the MERPlantas criteria. Hampea montebellensis, H. breedlovei, and H. longipes were categorized as "at Risk of Extinction," (En Peligro de Extinción ); H. latifolia was categorized as "Threatened" (Amenazada) and $H$. stipitata, H. mexicana, and H. tomentosa categorized as "Subject to Special Protection" (Sujeto a Protección Especial).

Conclusions. The species $H$. breedlovei, $H$. montebellensis, $H$. longipes, $H$. latifolia, $H$. mexicana, $H$. stipitata and $H$. tomentosa need to be included in ex situ and in situ conservation programs.

Key words: Conservation, cotton tribe, wild crop relatives.

\section{Resumen}

Antecedentes. El género Hampea (Malvaceae: Gossypieae) está compuesto por 21 especies y se encuentra en México, América Central y Colombia. México tiene once especies de las cuales, siete son endémicas. Hampea es de interés especial para la conservación porque son plantas silvestres parientes del algodón cultivado y algunas especies son amenazadas por actividades antropogénicos.

Preguntas. ¿Cuál es el estatus de conservación de las especies de Hampea en México?

Sitio y años de estudio. Se realizaron observaciones en el campo en el sur de México durante 1991-1995, 2012 y 2016. Se obtuvieron datos de especímenes de los base de datos de CONABIO y datos de herbarios nacionales e internacionales de 2014-2016.

Métodos. El estatus de conservación del género Hampea en México fue evaluado usando los criterios de Método de Evaluación del Riesgo de Extinción de Plantas (MER-Plantas) de NOM-059-SEMARNAT2010. La distribución potencial y de las especies fueron evaluadas con el algoritmo Maximum Entropy y datos biológicos fueron obtenidos de una revisión de la literatura y de observaciones en el campo.

Resultados. Siete especies del género Hampea fueron consideradas entre un criterio de riesgo de MERPlantas. Hampea montebellensis, H. breedlovei y H. longipes fueron categorizadas como "En Peligro de Extinción"; H. latifolia como "Amenazada" y H. stipitata, H. mexicana y H. tomentosa fueron consideradas como "Sujeto a Protección Especial."

Conclusiones. Las especies $H$. breedlovei, $H$. montebellensis, $H$. longipes, $H$. latifolia, $H$. mexicana, $H$. stipitata, y H. tomentosa requieren ser incorporadas en programas de conservación ex situ e in situ.

Palabras Clave: conservación, parientes plantas cultivadas, tribu de algodón. 
he cotton tribe (Malvaceae: Gossypieae) is composed primarily of genera with either widespread pantropical distributions (Gossypium L., Thespesia Sol. ex Corrêa, Cienfuegosia Cav.) or of genera with highly endemic distributions restricted primarily to oceanic islands (Kokia Lewton, Lebronnecia Fosberg \& Sachet, Gossypioides Skovsted, Cephalohibiscus Ulbr.) (Fryxell 1979, Areces-Berazain \& Ackerman 2016). The exception to this pattern is the genus Hampea Schltdl., which although tropical, is restricted to the American Continent with a relatively widespread distribution of species extending from central Mexico into northern Colombia (Fryxell 1979). The genus is also unique in being the only members of the tribe to be primarily dioecious (Figure 1) and to have an arillate fruit (Figure 2). The genus is composed of 21 species of small to medium-sized trees with relatively restricted distributions (Fryxell 1979, 1980). Mexico has the greatest richness of Hampea with 11 of the 21 species, followed by Guatemala with seven species (Fryxell 1968, 1969, 1979, 1980, 1988). Species of Hampea occur in wet to seasonally dry tropical forests and tropical montane cloud forests, from sea level to elevations below the frost line (Fryxell 1979) and range in abundance from very common to very rare (Fryxell 1968).

One species in Mexico is listed in the IUCN Red List, H. montebellensis Fryxell, as "Endangered" (González-Espinosa 1998, IUCN 2012) and is also listed in the Mexican list of species at risk (NOM-059-SEMARNAT-2010) as "Threatened." Several species outside of Mexico are also listed in the IUCN Red list and include: H. micrantha A.Robyns in Panama, H. sphaerocarpa Fryxell from the Caribbean coast of Guatemala and Honduras, H. reynae Fryxell found in El Salvador, and H. thespesioides Triana \& Planch., from central Colombia (IUCN 2012). Within Mexico, various species are also apparently threatened by deforestation and agricultural expansion (Jones \& Baro-Peruyero 2002, Jones 2001 González-Espinosa 1998), although these have not been systematically evaluated.

Species of Hampea are of particular interest for conservation because, as members of the cotton tribe Gossypieae, they represent wild relatives of cultivated cotton (Gossypium). The conservation of wild crop relatives has long been recognized as a priority for development of sustainable options for world agriculture (Frankel 1970, Meulleur \& Hodgkin 2004, Maxted et al. 2012). In the case of Hampea, several species share similar insect herbivore guilds with those found on cultivated cotton, including several important pest species such as the boll weevil, Anthonomus grandis Boheman (Coleoptera: Curculionidae) and the pink bollworm (Pectinophora gossypiella Saunders) (Burke et al. 1986). In addition, more species of parasitoids associated with the boll weevil have been reported from species of Hampea than from all species of wild or cultivated cotton (Cate et al. 1990, Jones 2001). Of the evaluated parasitoids, Catolaccus grandis Burks, has displayed promise as an effective control agent of the boll weevil in commercial cotton (Summy et al. 1992, Morales-Ramos et al. 1998). Also, the association of Hampea with the boll weevil and other pests may have apparently resulted in the evolution of effective characters that impart resistance against insect damage (Cate et al. 1990, Jones 1994, Jones \& Baro-Peruyero 2002).

The objective of the present work is to evaluate the conservation status of the genus Hampea in Mexico using the Methods of the Evaluation of Risk of Extinction of Plants (MER-Plantas) developed by the Mexican Ministry of Environment and Natural Resources (NOM-059-SEMARNAT-2010,SEMARNAT 2010). The evaluation was conducted given the apparent conservation risk to several species of Hampea in Mexico, and also because of the added importance given that species of this genus are wild relatives of cultivated cotton and share related insect pests and their natural enemies. In addition, the present work will address questions of the general conservation status of species of Hampea, given that it is a poorly studied plant genus with greatest diversity in Mexico and Central America and with seven species endemic to Mexico.

\section{Materials and Methods}

Data records. Specimen data of Hampea were obtained from the following herbaria: Paul Fryxell herbarium (pf) now part of the New York Botanical Garden herbarium (NY); Herbario Nacional de México, México D.F. (MEXU); Instituto de Ecología, Xalapa, Veracruz, México (XAL); El Colegio de la Frontera Sur, San Cristóbal, Chiapas, México (CH); and el Herbario de la Universidad Autónoma de Querétaro "Jerzy Rzedowski," Querétaro, México (QMEX). Data 

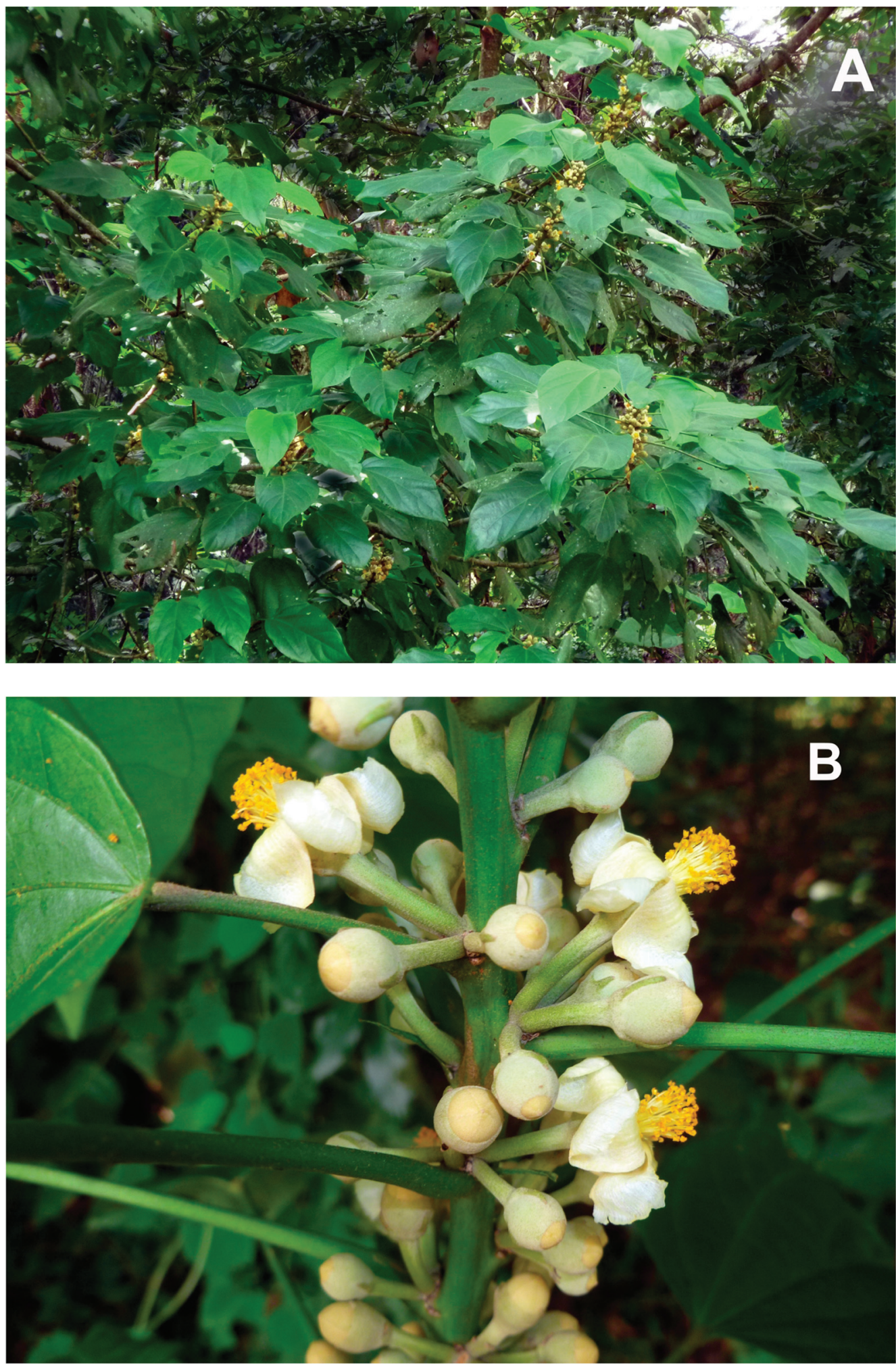

Figure 1. Hampea integerrima Schlechtendal, $2.5 \mathrm{~km}$ SW Xalapa, Veracruz, 1,348 m asl, 19³0'50', $\mathrm{N} ; 9^{\circ} 56^{\prime} 30^{\prime \prime} \mathrm{W}$; A. Portion of flowering branch of small tree. B. Close up of fasciculate, staminate flowers. 


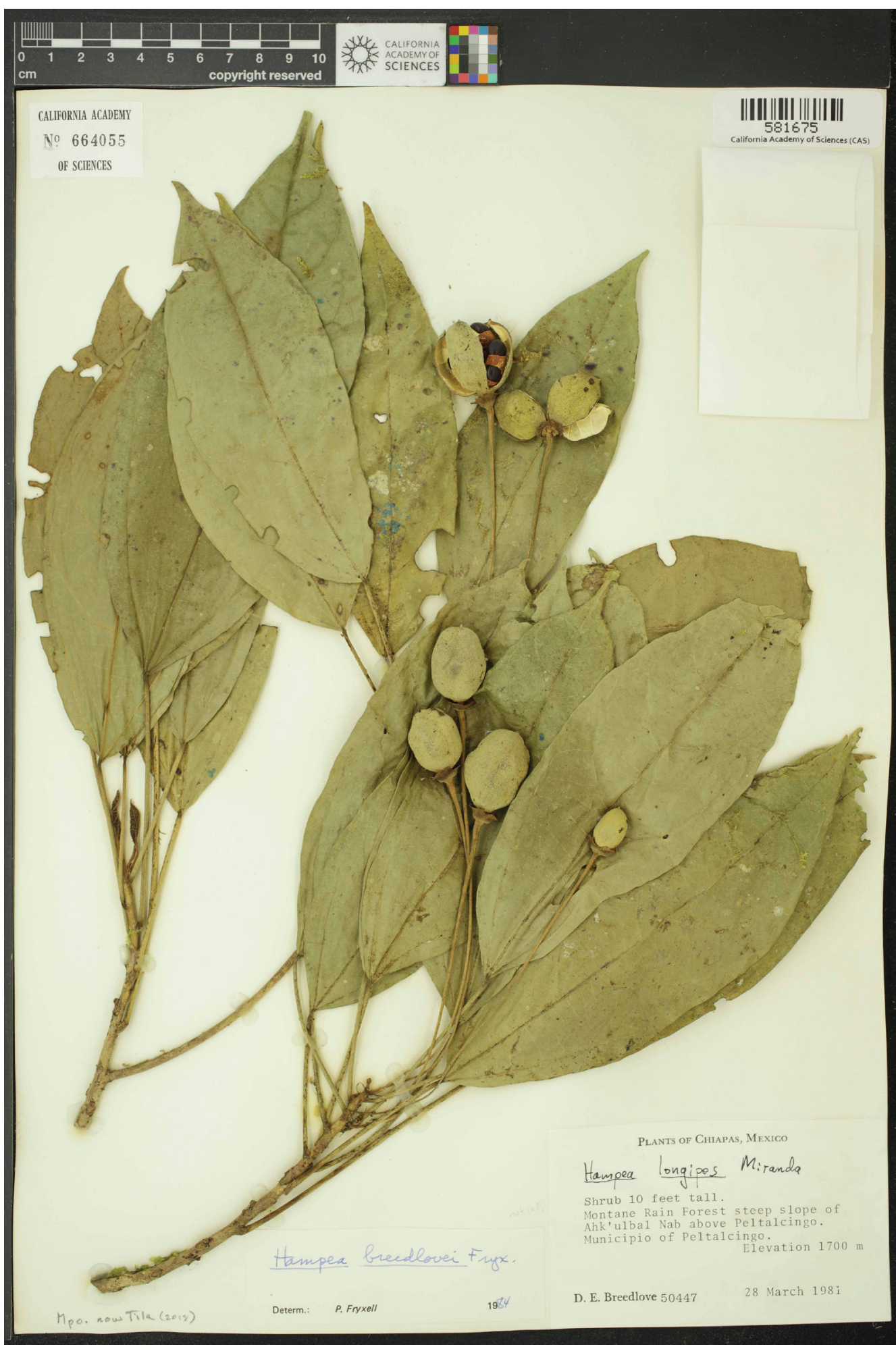

Figure 2. Herbarium specimen of Hampea breedlovei Fryxell from Cerro Ahk'ubal Nab, from municipality of Tila above Peltalcingo, Chiapas, Mexico Only known specimen series collected from a site other than type locality from the herbarium of California Academy of Sciences (CAS). Photograph by Rebecca Peters, California Academy of Science. 
from these herbaria were cross-referenced with that of the online national Mexican data base of the National Commission for the Knowledge and Use of Biodiversity (CONABIO 2016). Observations and collection data by the authors conducted during the last 25 years were also incorporated into the data base. Distribution data was evaluated and data points selected based the author's validation of species identity and quality of locality data.

A total of 218 records were used to generate the niche models, the total records used per species were: $H$. breedlovei Fryxell, 9; H. integerrima Schltdl., 36; H. latifolia Standl., 8; $H$. longipes Miranda, 12; H. mexicana Fryxell, 12; H. montebellensis Fryxell, 8; H. nutricia Fryxell, 47; H. rovirosae Standl., 16; H. stipitata S. Watson, 30; H. tomentosa (C.Presl.) Standl.,10; and $H$ trilobata Standl. 30.

Environmental variable selection for modeling of potential distribution. We considered 20 variables to generate the ecological niche models: 19 climatic variables and a variable for soil type. The climatic variables used were specific to Mexico using information from climatic stations for the period 1910 to 2009, in turn represent annual averages, seasonality and extreme factors potentially correlated with the presence of the species (Cuervo-Robayo et al. 2013). All variables were used in raster format with a $1 \mathrm{~km}^{2}$ resolution. The soil map used was "Conjunto de Datos Vectoriales Edafológico", scale of 1:250,000, Serie II (INEGI 2016)

To insure independence of variables (Tsoar et al. 2007), a selection of the most important variables from the 20 initial set was performed, which in turn resulted in lowered inter-variable correlations based on a Pearson correlation matrix for the variables using SPSS 20 (IBM 2011). A coefficient of $(r)>0.7$ in the resulting matrix was selected to identify the most correlated variables, and variables that showed the lowest correlation coefficients $(r)<0.7$, were used to generate the niche models for the species (Table 1).

Algorithm parameters. Potential distribution and environmental suitability predictions for species were performed with the Maximum Entropy Algorithm program (Maxent $^{\circledR}$; Version 3.3.3k) (Phillips et al. 2006). Algorithm widely used to understand the relationship between environmental variables and the presence of species (Elith et al. 2011).

The program's default settings used were: regularization multiplier in one, convergence threshold in $10^{-5}$ and the maximum number of background points in 10,000 (which serve as pseudo-absences for Maxent analyzes) was maintained. A maximum of 1,000 iterations (Phillips et al. 2006) were chosen and the selection of the Extrapolate and Clamping options, which are used to generate future predictions, was omitted.

Hampea integerrima, $H$. rovirosae, $H$. trilobata, $H$. nutricia and $H$. stipitata, had between 16 and 47 presence records, with which 10 replicates were generated per species, using the "random seed" and "subsample" options and a random test percentage of $20 \%$, used in similar works (Lodoño-Murcia \& Sánchez-Cordero 2011). This allowed the program to use that per-

Table 1. Description of the variables used to generate the niche models in Maxent in determination of potential distribution of species of Hampea in Mexico.

\begin{tabular}{|c|c|}
\hline CODE & BIOCLIMATIC VARIABLES \\
\hline $\mathrm{BIO} 1$ & Annual Mean Temperature \\
\hline $\mathrm{BIO} 2$ & $\begin{array}{r}\text { Mean Diurnal Range (Mean of monthly (max temp } \\
-\min \text { temp)) }\end{array}$ \\
\hline $\mathrm{BIO} 3$ & Isothermality $((\mathrm{BIO} 2 / \mathrm{BIO} 7) \times 100)$ \\
\hline $\mathrm{BIO} 4$ & Temperature Seasonality (standard deviation $\times 100$ ) \\
\hline $\mathrm{BIO13}$ & Precipitation of Wettest Month \\
\hline $\mathrm{BIO} 14$ & Precipitation of Driest Month \\
\hline $\mathrm{BIO15}$ & Precipitation Seasonality (Coefficient of Variation) \\
\hline $\mathrm{BIO} 17$ & Precipitation of Driest Quarter \\
\hline Edaphology & Soil classification \\
\hline
\end{tabular}


centage to generate a Receiver Operating Characteristic (ROC) curve for each model, with an associated value of AUC (area under the curve) for both sets of data, with $80 \%$ to generate the model and $20 \%$ to test it (Phillips \& Dudik 2008). Models with an AUC above 0.75 were considered to be potentially good predictive models (Elith et al. 2002, Phillips et al. 2006). Based on the above criteria, only one model of the 10 replicates generated by species was chosen with those with an AUC higher than 0.85 (Marmion et al. 2009).

For the species with fewer than 15 records, $H$. breedlovei, H. latifolia, H. longipes, H. mexicana, $H$. montebellensis and $H$. tomentosa, all records available for each species were used to generate each of the models, without using $20 \%$ of them as a test within the program and without generating replicas. In these cases, the criteria to make ecological niche predictions only required presence records and thus, was less sensitive to the record numbers (Hernández et al. 2006), and in some cases, five records was sufficient to generate a useful model (Pearson et al. 2007).

The ecological niche spatial predictions generated with Maxent have a scale of 0 (not suitable) to 1 (highly adequate), this probability influences the distribution of the species (Phillips et al. 2006). In all models, the logistic output format and the ACII format for the predictions were selected which allowed for a simpler interpretation of the model. The Jackknife analysis was also used to examine the contribution of each environmental variable (Phillips \& Dudik 2008)

Threshold cut selection. Although there are different alternatives to determine optimal threshold selection to transform the resulting probability into absence-presence data on a map (Freeman \& Moisen 2008), there are no set rules to determine an optimal threshold (Hu \& Jiang 2010). Due to characteristics of the collection records and based on recommendations of Freeman \& Moisen (2008), a threshold corresponding to the 10th percentile was chosen, removing from the final projection $10 \%$ of the distribution predicted by Maxent for the final models of each species.

Determination of the category of risk. The conservation status of species of Hampea in Mexico was evaluated using criteria given in the Methods of the Evaluation of Risk of Extinction of plants (MER-Plantas) of the Mexican Ministry of Environment and Natural Resources (NOM059-SEMARNAT-2010,SEMARNAT 2010). The four criteria of this method of the evaluation include: Criteria A, characteristics of the geographic distribution; Criteria B, habitat characteristics; Criteria $\mathrm{C}$, intrinsic biological vulnerability, and Criteria $\mathrm{D}$, impact of human activity. The details for evaluation of these criteria and the assignation of points are given in Nom059-SEMARNAT-2010-Anexo Normativo (SEMARNAT 2010). The amplitude of distribution (Criteria A.1) was calculated using the area of the potential distribution of each species calculated in the present work, in proportion to the total surface area of Mexico. The final variables used for the analysis of distributions were based on the independence of all variables with only those with a Pearson correlation of $r<0.8$, used in the final analysis. The number of populations (Criteria A.2) was determined counting separate, non-overlapping data points ( $3 \mathrm{~mm}$ ) discernable on a map of 1: 4,000,000 (SEMARNAT 2010). The number of biogeographic provinces and vegetation types that species occurred was determined by mapping data points on the map of the biotic provinces (CONABIO 2016) and vegetation types (CONABIO 2016) as given in the MER Criteria (SEMARNAT 2010) on a scale of 1:4,000,000.

\section{Results}

Table 2 presents the evaluation of the four criteria of MER-Plantas and point system for all species of Hampea in Mexico. Based on the evaluation of the criteria and the assigned points, each species was categorized within a category of risk of extinction (Table 2). The species, H. montebellensis, presently listed as "Endangered" in the NOM-059-SEMARNAT-2010 (SEMARNAT 2010), as well as, $H$. breedlovei and $H$. longipes were categorized as "At Risk of Extinction" under the MER-Plantas criteria. The species, H. latifolia was categorized as "Threatened" and $H$. stipitata, H. mexicana, and H. tomentosa were considered as "Subject to Special Protection." The species, $H$. nutricia, $H$. intergerrima, $H$. trilobata and $H$. rovirosae were not categorized in a threatened category and considered of least concern for conservation measures. 
Table 2. Criteria of Risk Category (MER-Plantas) ${ }^{1}$ for species of Hampea (Tribu Gossypieae: Malvales: Malvaceae) reported from Mexico. Species abbreviations: breed $=H$. breedlovei; interg $=H$. intergerrima; longi $=H$. longipes; monti $=H$. montebellensis; nutri $=H$. nutricia; stipi $=H$. stipitata; trilo $=H$. trilobata; latif $=H$. latifolia; mexic $=H$. mexicanus; tomte $=H$. trilobat and rovir $=H$. rovirosae. Conversation status abbreviations SEMARNAT (2010): P=En Peligro de Extinción (Risk of Extinction); A=Amenazada (Threatened); Pr=Sujeto a Protección Especial (Subject to Special Protection); MP= Menor Preocupación (Least Concern).

Criteria

Species of Hampea

Section Hampea

Section Standleya

Section

Section Hampea

latif mexic tomte

Eohampea

breed interg longi monti nutri stipi trilo latif mexic
A. Characteristics of the Geographic Distribution

A.1. Area Distribution

A.2. Number populations

A.3.Biogeographic provinces

A.4 Population representation

Sum/Proportion

B. 1 In various vegetation types

B.2 Specialized habitat

B.3 Dependent on Primary Habitat

B. 4 Needs particular regime of disturbance

B. 5 Limits of range in altitude

B. Sum/Proportion

C.1.1 Total \# of Individuals

C.1.2 Recruitment

C.1.3.a Density dependent reproduction

C.1.3b Clonality

C.1.3.c Population decline

C.1.3.d High variation fecundity

C.1.3.e Dioecious

C.1.3.f Gregarious/ Synchronous flowering

C.1.3.g Few propagules

C.2.1 Molecular Variation

C.2.2. GeneticStructure

C.2.3 Amount genetic variation

C.2.4 Population differentiation

C.3.1 Requires nurse plant

C.3.2 Requires host organism

C.3.3 Specific pollinator required

C.3.4 Specific dispersal agent required

C.3.5 Myrmecophile required

C.3.6 Specific mycorrhiza association

C.3.7 High biotic mortality (predator or pathogen)

C. Sum/Proportion

D.1 Effect of anthropogenic disturbance

D.2 Level of anthropogenic impact on habitat

$\begin{array}{ccccccccccc}3 & 3 & 3 & 3 & 1 & 3 & 1 & 3 & 2 & 2 & 2 \\ 3 & 1 & 2 & 3 & 0 & 1 & 1 & 2 & 2 & 2 & 1 \\ 3 & 2 & 2 & 2 & 2 & 2 & 2 & 2 & 2 & 2 & 2 \\ 0 & 0 & 0 & 0 & 0 & 0 & 0 & 0 & 0 & 0 & 0 \\ 9 / 11 & 6 / 11 & 7 / 11 & 8 / 11 & 3 / 11 & 6 / 11 & 4 / 11 & 8 / 11 & 6 / 11 & 6 / 11 & 5 / 110.45 \\ 0.82 & 0.55 & 0.64 & 0.73 & 0.27 & 0.55 & 0.36 & 0.64 & 0.55 & 0.55 & \end{array}$

\section{B. Characteristics of the Habitat}

$\begin{array}{ccccccccccc}3 & 0 & 2 & 1 & 0 & 2 & 1 & 2 & 1 & 2 & 2 \\ 0 & 0 & 0 & 0 & 0 & 0 & 0 & 0 & 0 & 0 & 0 \\ 1 & 0 & 1 & 1 & 0 & 1 & 0 & 1 & 1 & 1 & 0 \\ 0 & 0 & 0 & 0 & 0 & 0 & 0 & 0 & 0 & 0 & 0 \\ 3 & 2 & 2 & 1 & 1 & 1 & 2 & 1 & 2 & 1 & 2 \\ 7 / 9 & 2 / 9 & 5 / 9 & 3 / 9 & 1 / 9 & 4 / 9 & 3 / 9 & 4 / 9 & 4 / 9 & 4 / 9 & 4 / 9 \\ 0.78 & 0.22 & 0.56 & 0.33 & 0.11 & 0.44 & 0.33 & 0.44 & 0.44 & 0.44 & \end{array}$

\section{Intrinsic Biological Vulnerability}

C.1 Demographic Characteristics

$\begin{array}{lllllllllll}2 & 0 & 0 & 2 & 0 & 0 & 0 & 2 & 1 & 1 & 0 \\ 0 & 0 & 0 & 0 & 0 & 0 & 0 & 0 & 0 & 0 & 0 \\ 0 & 0 & 0 & 0 & 0 & 0 & 0 & 0 & 0 & 0 & 0 \\ 1 & 1 & 1 & 1 & 1 & 1 & 1 & 1 & 1 & 1 & 1 \\ 1 & 0 & 1 & 1 & 0 & 0 & 0 & 1 & 1 & 0 & 0 \\ 0 & 0 & 0 & 0 & 0 & 0 & 0 & 0 & 0 & 0 & 0 \\ 1 & 1 & 1 & 1 & 1 & 1 & 1 & 1 & 1 & 1 & 0 \\ 1 & 0 & 1 & 1 & 1 & 1 & 0 & 0 & 1 & 0 & 0 \\ 0 & 0 & 0 & 0 & 0 & 0 & 0 & 0 & 0 & 0 & 0\end{array}$

\section{C.2 Genetic Characteristics}

$\begin{array}{lll}0 & 0 & 0 \\ 0 & 0 & 0 \\ 0 & 0 & 0 \\ 0 & 0 & 0\end{array}$

C.3 Specialized Biotic Interactions

$\begin{array}{ccccccccccc}0 & 0 & 0 & 0 & 0 & 0 & 0 & 0 & 0 & 0 & 0 \\ 0 & 0 & 0 & 0 & 0 & 0 & 0 & 0 & 0 & 0 & 0 \\ 0 & 0 & 0 & 0 & 0 & 0 & 0 & 0 & 0 & 0 & 0 \\ 1 & 1 & 1 & 1 & 1 & 1 & 1 & 1 & 1 & 1 & 1 \\ 0 & 0 & 0 & 0 & 0 & 0 & 0 & 0 & 0 & 0 & 0 \\ 0 & 0 & 0 & 0 & 0 & 0 & 0 & 0 & 0 & 0 & 0 \\ 0 & 0 & 1 & 0 & 0 & 0 & 0 & 0 & 0 & 0 & 0 \\ 7 / 23 & 3 / 23 & 6 / 23 & 7 / 23 & 4 / 23 & 4 / 23 & 3 / 23 & 6 / 23 & 5 / 23 & 4 / 23 & 2 / 230.09 \\ 0.30 & 0.13 & 0.26 & 0.30 & 0.17 & 0.17 & 0.13 & 0.26 & 0.22 & 0.17 & \end{array}$

\section{Impact of Human Activity}

$-1$

$-1$

0 


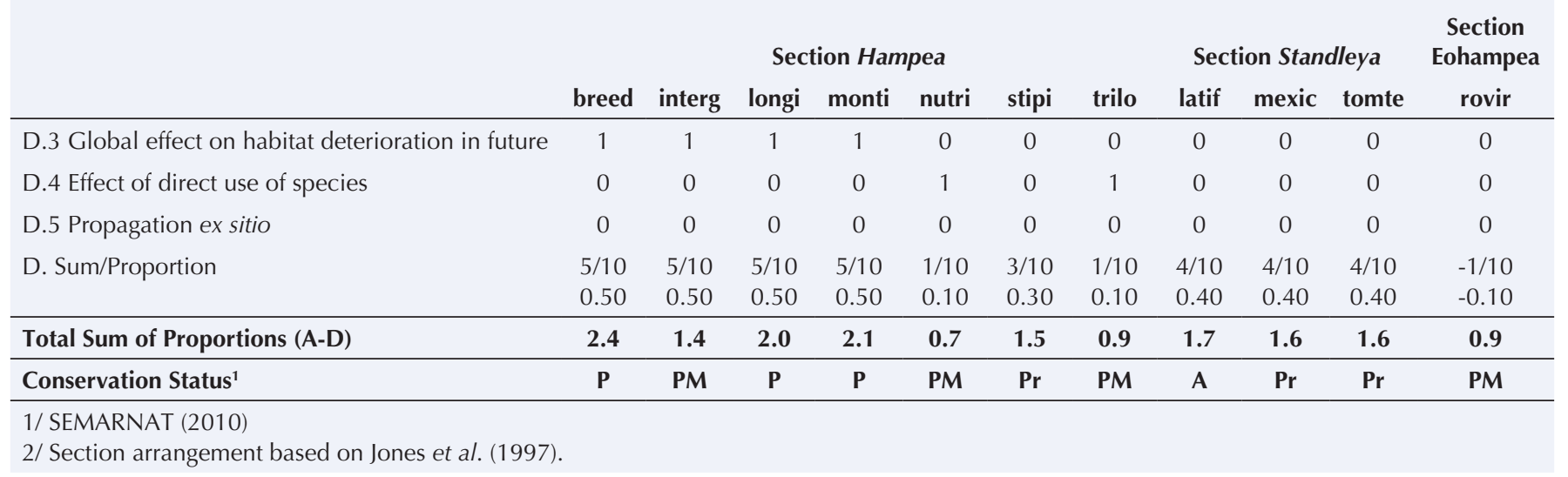

\section{Discussion}

Criteria A. Characteristics of the geographic distribution. Hampea breedlovei had the smallest area of distribution, calculated as the potential distribution, of analyzed species of Hampea, and represented $0.02 \%$ of the Mexican territory (Criteria A.1 = 3; Figure 3, upper left). Initially, this species was only known from the type locality when described by Fryxell in 1977 which was listed as: Mexico: Chiapas: Municipality of Rayon, in the Selva Negra $10 \mathrm{~km}$ above Rayon Mezcalapa along road to Jitotol. Although 10 separate collection sites appear in the Bios CONABIO data base (CONABIO 2016) within $15 \mathrm{~km}$ of the type collection site, some of these points apparently represent the same samples that were assigned different coordinates. Only two sites are not within the vicinity of the type collection: the first is one specimen $12 \mathrm{~km} \mathrm{~S}$ of Tila (Municipality: Tila) above Petalcingo, Chiapas at 1,700 $\mathrm{m}$ (Figure 2) and the second reported is from Veracruz, municipality of Acajete, west of Xalapa. This latter record is almost certainly a misidentification of $H$. integerrima given that this latter species is common in the western area of Xalapa (Figure 1, personal observation, RWJ).

Hampea latifolia was the species with the second smallest distribution representing $0.14 \%$ of the Mexican territory (Criteria A.1 = 3, Figure 3, upper right). This species is an endemic of the Soconusco region of southeastern Chiapas and adjacent departments of Retalhuleu and Suchitepéquez in southwestern Guatemala. Within Mexico, only four specimens were found in the National Autonomous University of Mexico (UNAM) herbarium and only one collected after 1980. In Chiapas, Jones (1994) observed five trees in forest fragments and in cacao plantations near the town of Palo Seco in the municipality of Tapachula, and seven trees from 11 to 19 $\mathrm{km}$ north the municipal seat of Mapastepec, in the foothills of the Cerro El Triunfo, near sites recorded for the MEXU herbarium collections.

Hampea montebellensis is another species with very limited distribution occurring within $0.15 \%$ of the Mexican territory (Criteria A.1 = 3, Figure 3, middle left). The species has only been found from central and eastern Chiapas from 900 to $1,500 \mathrm{~m}$ in moist forests (Fryxell 1988). Of the 44 specimen records in the CONABIO data base (CONABIO 2016), only four of the localities were not from within or in the vicinity of the Lagunas de Montebello National Park.

Hampea longipes had a potential distribution that covered $0.99 \%$ of the Mexican territory (Criteria A.1 = 3, Figure 3, middle right). Individuals of this species have been well collected in the state of Chiapas and Oaxaca, with 95 records in the CONABIO data base (CONABIO 2016). Recorded collection of this species indicates that it is endemic to the highlands ("Los Altos") of northern Chiapas and also found at elevations above $1,000 \mathrm{~m}$ in the adjacent Chimalapas region of eastern Oaxaca. Although, the potential distribution suggests that this species may occur in the Sierra Madre de Chiapas, no herbarium specimens from the region were found and flora studies (El Triúnfo) do not mention species of Hampea (Martínez-Meléndez et al. 2008, Pérez-Farrera et al. 2012). Specimens of Hampea in the central highland region of Oaxaca 


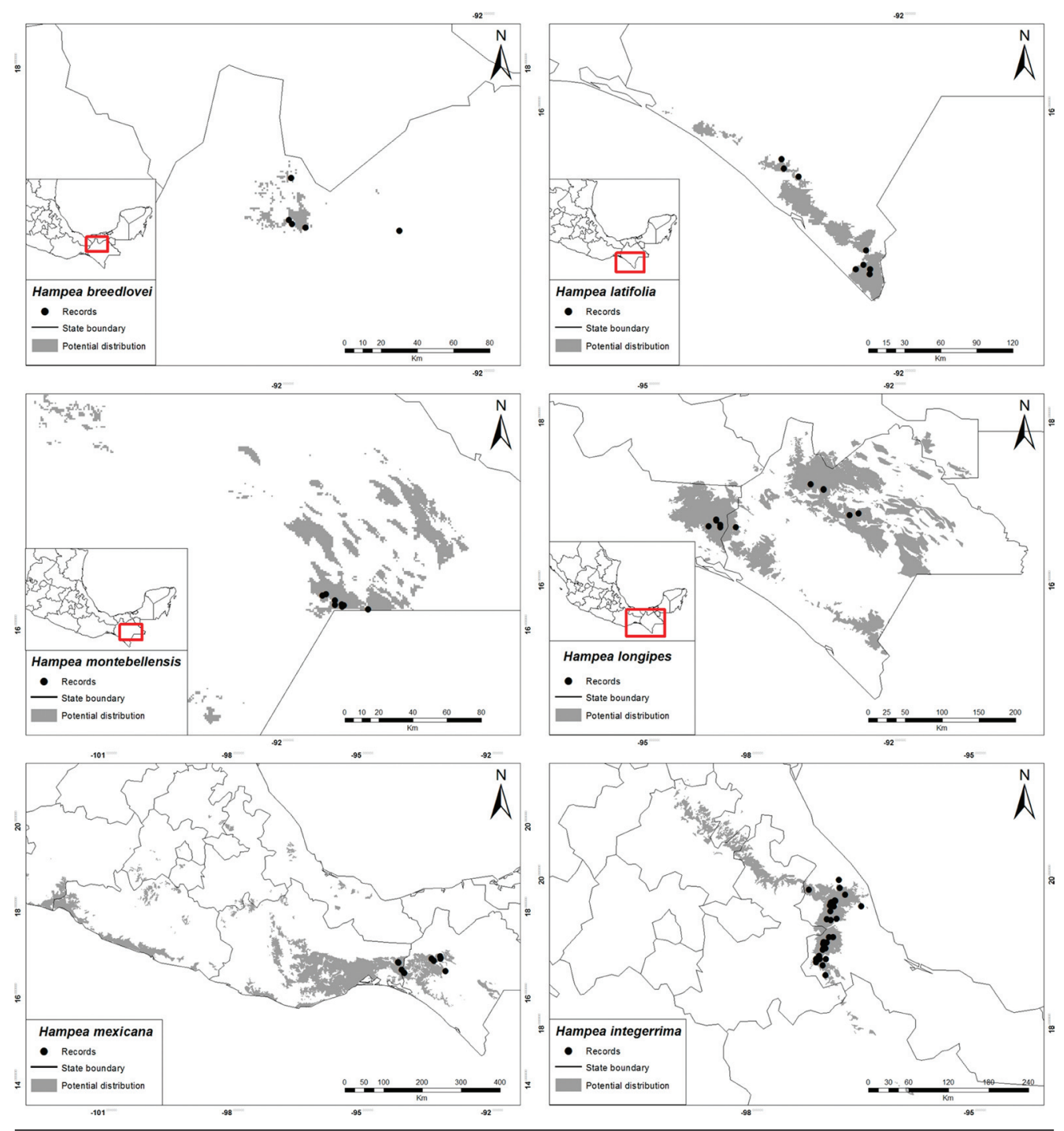

Figure 3. Potential distribution of six species of Hampea in Mexico: Upper left, Hampea breedlovei Fryxell; upper right, Hampea latifolia Standley; middle left, Hampea montebellensis Fryxell; middle right, Hampea longipes Miranda; bottom left, Hampea mexicana Fryxell; bottom right, Hampea integerrima Schlechtendal.

have been identified as both $H$. longipes and H. intergerrima, but no fruiting specimens were observed in herbaria to verify species identity from this state.

The potential distribution of $H$. mexicana presented here (Figure 3, lower left) represents $1.74 \%$ of the Mexican territory ( $1=2$ ). This distribution is within the central Depression of Chiapas, extending into the Chimalapa region of eastern Oaxaca in seasonally dry forests, from 800 to $1,000 \mathrm{~m}$. However, there are no records of the species from central Oaxaca and Guerrero as indicated by the potential distribution. Also specimens misidentified as H. stipitata were frequently found in various herbaria, especially from the Lacandon region giving the erroneous impression that the distribution of $H$. mexicana encompasses northern and northeastern Chiapas.

The distribution of H. integerrima in the southern Sierra Madre Oriental (SMO) and tropical portions of the Neovolcanic axis in Veracruz within populated areas near the montane forests around Córdoba and Xalapa, Veracruz (Figure 3, lower right) has resulted in this species being one of the most collected of the genus. The species has not been reported much further north than $20^{\circ}$ latitude, although the potential distribution suggests that suitable humid montane habi- 
tat extends north to Tamaulipas and covers $0.38 \%$ of the national territory (Criteria A. $1=3$ ). Additionally, the potential distribution extends from the SMO through the Neovolcanic Axis into Oaxaca, but there are only a few specimens from this state in herbaria and all samples seen were vegetative, making identification difficult. Trees were observed in the field in Veracruz by the authors including on the western edge of Xalapa, near the Cascada de Texolo, the slopes of Cerro Orizaba, and in the outskirts of Córdoba.

Hampea stipitata is relatively well represented in herbaria (CONABIO 2016) although its distribution covers only $0.33 \%$ of Mexico (Critiera A1 $=3$ ), suggesting that the species is common in portions of its distribution. This species is restricted to southern Mexico in lowland tropical forests of southeastern Veracruz, northeastern Oaxaca into the Lacandón region of Chiapas (Figure 4, upper left) and extends into the Petén region of Guatemala. The distribution of the species also extends south from the lowland areas of Lacandón region to the west central region of Chiapas, reaching forests at altitudes close to $1,000 \mathrm{~m}$ in the municipalities of Berriozábal and Ocozocoautla.

Hampea trilobata is essentially a Yucatán peninsula endemic (Figure 4, upper right). There are more specimens of this species in herbaria of Mexico than all other species, an indication of its relative high abundance, especially considering it is not a showy tree. Its distribution covers $7.00 \%$ of the Mexican territory (Critiera A1 $=1$ )

Hampea rovirosae is the only species with a marked disjunct distribution (Figure 4, middle left). It is a lowland species being found in humid tropical forests of extreme southern Veracruz, throughout Tabasco, northwestern Chiapas and southwestern Campeche but also reported from the Soconusco region of the Pacific coast of Chiapas near Puerto Madero (Bodegas-Valera et al. 1977). The species covers $1.20 \%$ of the Mexican territory (Criteria A.1 = 1).

The potential distribution of $H$. tomentosa is one of the more extensive that we calculated for the genus, covering $3.18 \%$ of the Mexican territory (Criteria A.1 = 2, Figure 4, middle right). However, the species is poorly represented in herbaria with only 36 recorded specimens in the CONABIO data base (CONABIO 2016), and was difficult to find in the field (RWJ, personal observation), suggesting low population densities.

The distribution of $H$. nutricia is one of the largest for the genus, ranging from northern Chiapas and Tabasco, eastern Puebla, and along the gulf coast of Veracruz, north almost to $22^{\circ}$ latitude (Figure 4, lower center) and covers $7.94 \%$ of Mexico (Criteria A.1 =1). It is mainly a lowland species but is also found in lower montane rain forests below 1,000 m (Fryxell 1988).

The number of populations and their presence in biotic provinces constitute Criteria A.2 and A.3, respectively. Two species had only one to three recorded populations (A.2.a =3): H. breedlovei ( 2 populations) and $H$. montebellensis (2). Four species had four to eight populations (A.2.b $=2$ ): and included: H. longipes (7), H. latifolia (4), H. mexicana (5), and H. tomentosa (7). Species with nine to 25 populations (A.2.c = 1): were: H. intergerrima, H. stipitata, and H. trilobata. The only species with greater than 26 populations $($ A.2.d $=0$ ) was Hampea nutricia. All species were found in two or three biogeographic provinces which places them all in Criteria A.3 3 .

None of the populations of species of Hampea in Mexico have what can be considered peripheral or extralimital distributions (Criteria A.4). Only five of the species, $H$. latifolia, $H$. mexicana, H. trilobata, H. longipes, and H. stipitata are not endemic to Mexico, and although these species have distributions that extend into Central America, a significant proportion of the populations, as suggested by areas of distribution and specimen records, are in Mexico (Fryxell 1979, 1988).

Criteria B. Characteristics of the Habitat. Species of Hampea in Mexico were found from one to five different vegetation types (Criteria B1). Hampea breedlovei was only recorded from cloud forests of northern Chiapas (B.1.a $=3$ ). Species recorded from two vegetation types were $H$. montebellensis, $H$. longipes, $H$. stipitata, $H$. latifolia and $H$. rovirosae $(\mathrm{B} .1 . \mathrm{b}=2)$. Those found in three vegetation types (B.1.c =1) were, H. trilobata, H. mexicana, and H. tomentosa. Hampea intergerrima and $H$. nutricia were reported from four and five vegetation types, respectively.

Several species of Hampea were considered to be dependent on primary habitat to sustain populations (Criteria B3) based on collection records and observations in the field. These spe- 


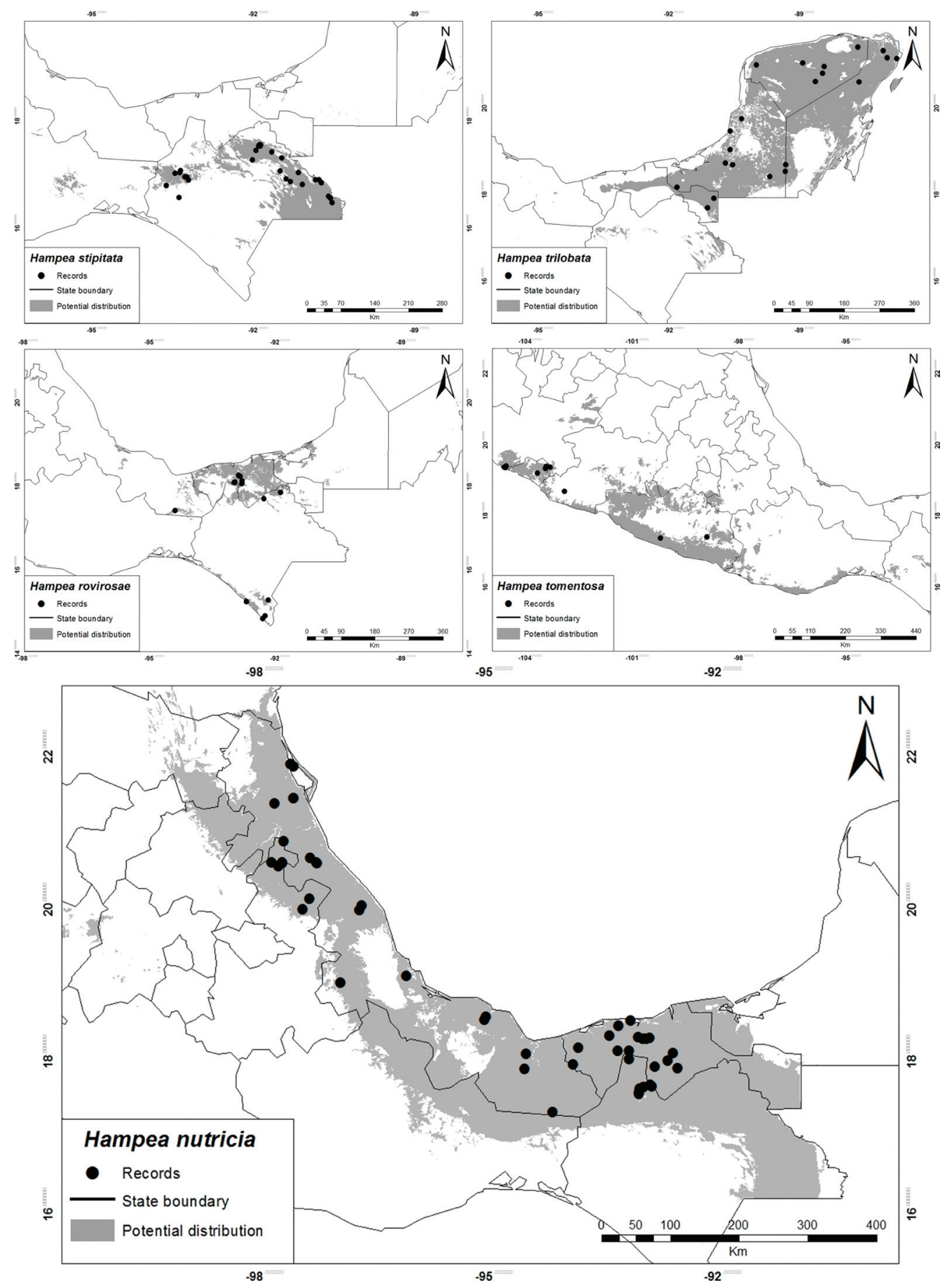

Figure 4. Potential distribution of five species of Hampea in Mexico: upper left, Hampea stipitata S. Watson, upper right, Hampea trilobata Standley; middle left, Hampea rovirosae Standley, middle right, Hampea tomentosa (Presl.) Standley, lower center, Hampea nutricia Fryxell.

cies were: $H$. breedlovei, $H$. longipes, $H$. mexicana, $H$. montebellensis, $H$. stipitata, and $H$. latifolia. For $H$. breedlovei, $H$. longipes, and $H$. montebellensis, these species are restricted to humid, montane habitats and no observations were reported or observed of individuals outside such habitat. For the primarily lowland or mid-altitude species, H. stipitata, H. mexicana and H. latifolia, individuals were invariably found associated with relatively undisturbed lowland tropical forests, although at times within small fragments. Never were individuals of these spe- 
cies observed in recently disturbed vegetation or in open areas as is frequently found with $H$. nutricia, $H$. trilobata, or $H$. rovirosae.

Species of the genus Hampea are relatively restricted in their range of altitude in Mexico (Critieria B.5). However, only H. breedlovei was considered to be restricted to an interval of less than $200 \mathrm{~m}$ in altitude (B.5 = 3), based on collection records and data given by Fryxell (1988). Reported altitudinal ranges (Fryxell 1988) and field observations indicated that $H$. integerrima, $H$. longipes, $H$. mexicana, $H$. trilobata, and $H$. rovirosae, although each were found at different altitudinal zones, are limited to an altitudinal range from 200 to $500 \mathrm{~m}(\mathrm{~B} \cdot 5=2)$. Hampea montebellensis, $H$. nutricia, H. stipitata, H. latifolia and H. tomentosa had the greatest ranges in altitude, from 500 to $1,000 \mathrm{~m}(\mathrm{~B} .5=1)$.

Two of the MER-Plantas habitat criteria did not apply to species of Hampea in Mexico. None of the species can be considered to have a highly specialized habitat (Criteria B.2). Likewise, there was no evidence that a species required a particular regime of disturbance for population maintenance (Criteria B.4).

Criteria C. Intrinsic biological vulnerability.- Quantitative field data for the demographic characteristics (Criteria C.1) of species of Hampea is lacking. However, it was considered possible to calculate population densities estimates for H. breedlovei (C.1.1) because of its highly reduced area of distribution. The calculated population density of $H$. breedlovei required to surpass criteria C.1.1.b (5,000 individuals) is $13.7 / \mathrm{km}^{2}$, or one tree per 7 ha, based on the predicted area of distribution. However, only 12 collections are reported for this species. Eleven of these are reported from the Selva Negra region above Rincón Chamula which has been highly altered and progressively fragmented with an almost complete reduction in forested area (RamírezMarcial et al. 2001, Cayuela et al. 2006). Only one other collection record exists outside the Selva Negra area from the isolated Cerro Ahk'ubal Nab, above Petalcingo (Figure 2), which is a forested area of less than $15 \mathrm{~km}^{2}$. Given the small area of distribution, the reduced number of collections and the present loss of habitat, it is highly improbable that there presently is a population density of 13.7 trees $/ \mathrm{km}^{2}$ of $\mathrm{H}$. breedlovei in the northern highlands of Chiapas. Thus, we conservatively categorized Criteria $\mathrm{C} 1$ as less than 5,000 individuals $(\mathrm{C} \cdot 1 . \mathrm{b}=2)$. Although other species probably have reduced populations as well, there was insufficient data to estimate population sizes $(\mathrm{C} \cdot 1 \cdot \mathrm{b}=0)$.

Other demographic characteristics (C.1) were as follows. Recruitment of seedlings were observed in most species with no data for the remainder, thus for all, C.1.2 $=0$. There is also no evidence of factors involved with density dependent reproduction (C.1.3a) in Hampea, nor is there evidence of clonality $(\mathrm{C} .1 .3 . \mathrm{b}=1)$ (personal observation, RWJ). All species except $H$. rovirosae are dioecious (Fryxell 1979), thus C.1.3.e $=1$ for all species except $H$. rovirosae (0). There is no evidence of high variation in fecundity, C.1.3.d =0 for all species. Fruiting in Hampea is not characterized by few propagules (C.1.3.g) and is often prodigious for large trees (Fryxell 1979, personal observation, RWJ).

There is evidence of population decline (C.1.3) for several species. Significant destruction of the type habitat of $H$. breedlovei is discussed previously. The destruction of the type habitat $H$. montebellensis within the Montebello National Park due to fires and deforestation habitat is well documented (Román-Cuesta \& Martínez-Vilalta 2006, Ramirez-Marcial et al. 2010, personal observation, RWJ). Study sites reported for H. longipes by Jones \& Baro-Peruyero (2002) in the municipality of Tenejapa have also been deforested along the Yoshib River. Deforestation due to agricultural activities has occurred in the Tapachula area of Chiapas, where Bodegas et al. (1977) reported the presence of $H$. rovirosae and H. latifolia. Subsequently, populations of H. rovirosae have not been found. Several individuals of H latifolia were found near the Bodegas collection sites (Jones 1994) but only within small forested fragments on the edge of cacao plantations or close to dwellings. Also, populations of H. latifolia in the lowland watershed of the Mapastepec River (MEXU, Jones 1994) are also in highly disturbed sites due to increased human populations along the river, and corresponding deforestation and agricultural activities that have intensified seasonal flooding and consequent damage to the floodplain.

Evidence of synchronous flowering (C.1.3), is reported by Fryxell (1988); who gives general flowering periods for species, and writes that for the genus, "flowering is definitely seasonal" 
(Fryxell 1979). Jones \& Baro-Peruyero (2002) followed the phenology of populations of $H$. montebellensis, $H$. longipes and H. mexicanus in Chiapas and reported that flowering periods of both sexes occurred over a period of less than three months for these species. Stansly (1985) reported similar flowering periods for $\mathrm{H}$. nutricia in Tabasco. However, H. trilobata has been collected with flowers in all months of the year (Herbario CICY 2018), and flowering is apparently not synchronous and for extended months in $H$. rovirosae, $H$. intergerrima and $H$. tomentosa.

No data is available for the following genetic evaluation (Criteria C.2) for the amount of heterocigosity, genetic structure, amount genetic variation, and population differentiation; thus all criteria were assigned zero (Criteria C.2.1-C.2.4.). Five of the seven specialized biotic interactions (Criteria C.3) have not been reported for Hampea. There is no data or the response was negative for important interactions with nurse plants, a parasitic interaction with a host plant, a specific pollinator, obligate myrmecophilia, or strict dependence on mycorrhizal association. All species, except $H$. breedlovei, were observed in the field and there was no evidence of clonal reproduction.

The two specialized biotic interactions pertinent to species of Hampea have to do with specific dispersal agents and high biotic mortality agent for one species. Hampea is unique within the cotton tribe for the presentation of the seeds within a white aril in a hanging open, fruit capsule (Figure 2), a trait considered an adaptation to dispersal by vertebrates (Howe \& Smallwood 1982). Birds have been reported feeding on seeds of Hampea (Fryxell 1979, Marini \& Cavalcanti 1998) indicating that the dispersal of seeds apparently requires a frugivorous vertebrate $($ C.3.3 = 1). For another specific biotic interaction $($ C.3.7 = 1), Jones \& Baro-Peruyero (2002) report that the herbivorous beetle, Anthonomus palmeri Jones \& Burke (Curculionidae) can destroy over $90 \%$ of the flower buds of $H$. longipes which may reduce plant fecundity.

Criteria D. Impact of Human Activity. Three lowland species are apparently favored by anthropogenic disturbance (Criteria D.1 = -1): H. nutricia, H. trilobata, and H. rovirosae (Fryxell 1969,1988 , personal observations, RWJ). In the case of $H$. nutricia, individuals are common on roadsides and often used as shade trees in patio and used in fence rows (Fryxell 1979). Hampea trilobata and $H$. rovirosae are also favored by disturbance and occur on the edge of clearings near dwellings and roadsides. Although the lowland species, H. stipitata, is common along roadsides in the Lacandón region of northeastern Chiapas, it is apparently not benefited by disturbance (D. $1=0$ ), as are H. nutricia, H. trilobata, or H. rovirosae and is more restricted to less disturbed lowland and montane tropical rainforests (Fryxell 1988). The final lowland species, H. latifolia is apparently negatively affected by disturbance (D.1 =1), as it is confined to small forest remnants and riparian vegetation within the highly developed agricultural region of the Soconusco (Fryxell 1988, Jones 1994).

Based on herbarium data and observations in the field, all remaining species were considered negatively affected by disturbance $(\mathrm{D} .1=1)$. This is especially evident in the montane species, $H$. breedlovei, $H$. montebellensis, $H$. intergerrima and $H$. longipes, which have not been reported from disturbed habitats. Given their rarity and their observed association with the relatively undisturbed habitats, the mid-altitude and dry forest species, Hampea mexicana and $H$. tomentosa are also considered negatively affected by human disturbance.

Anthropogenic disturbance of habitats (Criteria D.2) was considered to negatively affect to some degree all species of Hampea in Mexico, except H. trilobata. Of the most affected, Hampea breedlovei is restricted to cloud forest habitats of Northern Chiapas, of which few remain (Ramírez-Marcial et al. 2001). Cayuela et al. (2006) estimated that there are only 4,650 ha of primary cloud forest left in northern Chiapas; and noted that all forests were outside of protected areas and subject to high levels of deforestation $(\mathrm{D} .2=3)$. Although Hampea longipes has a greater distribution than $\mathrm{H}$. breedlovei, it is also present in the temperate and cloud forest habitats of northern Chiapas and thus, affected by high levels of deforestation (D.2 = 3).

Three species are found in areas of relatively high human population densities and heavily impacted by human activity (D.2 = 3), based on analysis by González-Abraham et al. (2015). Hampea intergerrima is found in the heavily populated regions of the eastern portions of the Neovolcanic axis of central Mexico. Hampea mexicana is found in scattered forest and riparian fragments, principally within the central depression Chiapas that also has a high level of hu- 
man impact and $H$. tomentosa, which is found on the relatively highly populated Pacific coast regions from Guerrero to southern Jalisco.

Hampea montebellensis is apparently restricted to the humid forest types within the vicinity of the Lagunas de Montebello National Park which have been significantly impacted (D.2 = 3). Although the park is a protected area, fires occurred in there during the El Niño years of 1998 and in 2003 (Román-Cuesta \& Martínez-Vilalta 2006). Deforestation has also occurred in order to facilitate tourist activities near lakes of the reserve, as well as from typical clearing of land for extraction and agricultural activities, although some reforestation efforts have been made (Ramírez-Marcial et al. 2010, personal observation, RWJ).

Hampea latifolia is an endemic of the Soconusco region which is considered to have one of the highest levels of human impact within Mexico, principally associated with the tropical lowland forest (González-Abraham et al. 2015). Because H. latifolia is a tropical forest species, the anthropogenic impact on this species is considered to be high (D.2 =3).

The habitat where H. stipitata is found is primarily the Lacandón region of northeastern Chiapas. Although much of this region is now protected, deforestation from the 1960s to 1990s was estimated to be as high as $40 \%$ (Bray et al. 2008). Deforestation rates have dropped in the last 20 years but conservation initiatives are complicated by ethnic tensions, poverty and land-tenure problems (Calleros-Rodríguez 2017). Populations of $H$. stipitata in central Chiapas (municipality of Berriozabal) are also threatened by high deforestation rates and population pressure in this region $(\mathrm{D} .2=3)$.

Although $H$. rovirosae and $H$. nutricia are tolerant of disturbance, their habitats are among the most impacted by human activity (González-Abraham et al. 2015). These species are considered to be moderately affected by habitat loss in some populations $(\mathrm{D} .2=1)$. Hampea trilobata occurs in some of the least disturbed habitats of the Yucatán peninsula with low human impact on habitats (D.2 $=0$ ).

We considered that all montane species, $H$. breedlovei, $H$. montebellensis, $H$. intergerrima and $H$. longipes, will be negatively impacted by the global effect on habitat deterioration in the future (Criteria D.3) due to climate change $(\mathrm{D} .3=1)$.). Climate models predict that of $68 \%$ of Mexican cloud forests will be lost by 2080 (Ponce-Reyes et al. 2012). The remaining species of Hampea were considered to be in habitats less affected by global effects or capable of adapting to changes given the seasonality of their present habitat $(\mathrm{D} .3=0)$.

The effect of direct use of species (Criteria D.4) on species of the genus Hampea is apparently minimal. The most cited direct use of most species is the fashioning of crude rope made from dried, unprocessed bark (Fryxell 1969). This use is reflected in the common name of Hampea, "majagua," which is often a general term for a variety of plants from which the bark is used for this same purpose (Fryxell 1969, Cobos et al. 2009, Veláquez et al. 2009, Aranguren \& Márquez 2011). The wood of Hampea trees is light and apparently not used much in construction (Fryxell 1969). Thus, we considered there was no effect of direct use of species (D4), except for moderate use for rope of H. nutricia and H. trilobata (D.4 =1). Also, we found no mention of the fruits being used for human consumption or evidence of species of Hampea being propagated ex situ or cultivated (D5 $=0$ ).

\section{Conclusions}

Based on a detailed evaluation of the criteria of MER-Plantas (SEMARNAT 2010), seven species of the genus Hampea in Mexico were in a category of risk. Three species were categorized as "Risk of Extinctión": H. montebellensis, H. breedlovei and H. longipes. Of the other four species, Hampea latifolia was categorized as "Threatened" in our analysis and H. stipitata, $H$. mexicana, and H. tomentosa were categorized as "Subject to Special protection". Formal requests will be made to SEMARNAT to change the status of these five species to their respective categories based on the results of our analysis. Also, the information presented in this study can be used to evaluate the species for inclusion in the IUCN Red List (IUCN 2017).

The first step in the conservation of $H$. breedlovei is to verify that the species still exists. The Cerro Ahk'ubal Nab in the municipality of Tila may be the only site left which may maintain populations of the species. Similarly, current population estimates are needed for the other 
at-risk species: $H$. montebellensis, $H$. longipes, $H$. latifolia, $H$. stipitata, $H$. mexicana and $H$. tomentosa. For all species, and especially those in the highlands of Chiapas, many of the populations are in areas presently under control of indigenous or independent political groups with which collaboration would be essential to initiate and establish in situ conservation efforts.

The three endangered species, $H$. montebellensis, H. breedlovei and H. longipes, could serve as flagship species for cloud forests habitats of Chiapas. This is especially pertinent for the appropriately named, $H$. montebellensis which is restricted to the Lagunas de Montebello National Park and surrounding areas. Information about the species could be provided to tourists and residents of the park through printed material or on-line, and individual trees could be identified in the field with permanent plaques highlighting the unique and endemic nature of the species. The species could also be used in the present reforestation programs for the park (RamírezMarcial et al. 2010), given that other species of Hampea have shown potential in reforestation programs in Costa Rica (Marquis \& Clark 1989).

These five species need to be included in regional and national in situ conservation programs for the preservation of sites with populations of these species, as well as, ex situ conservation programs for the cultivation in nurseries and botanical gardens and the inclusion in germplasm preservation, and maintenance. However, little information is available for ex situ conservation programs for propagation of Hampea. The first author has grown several trees of $H$. trilobata from rootstocks and the Central American species, Hampea appendiculata (D.Sm.) Standley has been grown from seedlings in outdoor experimental plots (Marquis \& Clark 1989). Fryxell (1979) reports that, "based on limited data," seeds of Hampea lose their viability in approximately a year, suggesting that they are intermediate between orthodox and recalcitrant seeds. Only two species were found to be in international seed banks, $H$. nutricia and $H$. appendiculata, in the Kew Gardens seed collection (Royal Botanic Gardens Kew 2018). Much more information is needed for the successful inclusion species of Hampea in ex situ conservation programs and germplasm preservation.

\section{Acknowledgement}

Funding was provided initially by the Consejo Nacional de Ciencia y Tecnología, (CONACYT), Ciencias Básicas, through the project, "Molecular systematics of the Anthonomus grandis species group (Insecta: Coleoptera: Curculionidae)", and overall support from the Facultad de Ciencias Naturales, Universidad Autónoma de Querétaro, Querétaro, México. Deborah Baro Peruyero, Peter Krauter and James Cate accompanied authors and provided input during several field explorations.

\section{Literature Cited}

Aranguren A, Márquez NJ. 2011. Etnoecología de las especies vegetales de los bosques estacionalmente secos del Estado Mérida. Ethnobotany Research and Applications 9: 307-323. DOI: 10.17348/ era.9.0.307-323

Areces-Berazain F, Ackerman JD. 2016. Phylogenetics, delimitation and historical biogeography of the pantropical tree genus Thespesia (Malvaceae, Gossypieae). Botanical Journal of the Linnean Society, 181: 171-198. DOI: 10.1111/boj.12414

Bodegas-Valera R, Flores-García R, Coss-Flores ME. 1977. Aspectos de interés sobre las hospederas alternantes del picudo del algodonero Anthonomus grandis y avances en la investigación respectiva en el Soconusco, Chiapas, Mexico. Centro de Investigaciones Ecológicas del Sureste, 3: 3-14.

Bray D, Duran E, Ramos VH, Mas JF, Velazquez A, McNab RB, Barry D, Radachowky J. 2008. Tropical deforestation, community forests, and protected areas in the Maya Forest. Ecology and Society, 13: 56. DOI: 10.5751/ES-02593-130256

Burke HR, Clark WE, Cate JR, Fryxell PA. 1986. Origin and dispersal of the boll weevil. American Entomologist, 32: 228-238. DOI:10.1093/besa/32.4.228

Cate JR, Krauter PC, Godfrey KE. 1990. Pests of cotton. pp. 17-29. In Habeck, D.H.Bennett F.D, Frank JH, eds. Classical Biological Control in the Southern United States. Southern Coop. Series Bull. 355 :

Cayuela L, Golicher DJ, Rey-Benayas JM. 2006. The extent, distribution, and fragmentation of vanishing montane cloud forest in the Highlands of Chiapas, Mexico. Biotropica 38: 544-554. DOI: 10.1111/ j.1744-7429.2006.00160.x 
Alatorre-Cobos J, Cano-Carmona E, Otero-Zaragoza R. 2009. Catálogo florístico de las plantas medicinales de la selva baja subcaducifolia de Acapulco, México. Boletín del Instituto de Estudios Giennenses. 200: 231-288.

Calleros-Rodríguez H. 2017. Etnia, medio ambiente y sistema político en la Selva Lacandóna. Revista del CESLA 20: 299-323 CONABIO (Comisión Nacional para el Conocimietno y Uso de la Biodiversidad) 2016. Acceso a las bases de datos de los nodos $<$ http://www.conabio.gob.mx/remib/doctos/remibnodosdb.html> (accessed March 15, 2016).

CONABIO [Comisión Nacional para el Conocimiento y Uso de la Biodiversidad]. 2016. Provincias biogeográficas de México. Escala $1: 4000$ 000. México. <http://www.conabio.gob.mx/informacion/gis/ layouts/rbiog4mgw.png> (accessed June 2016).

CONABIO. 2016. Vegetacion Potencial 1: 4'000,000. <http://www.conabio.gob.mx/informacion/gis > (accessed May 2016)

Cuervo-Robayo A, Téllez-Valdés O, Gómez-Albores MA, Venegas-Barrera CS, Manjarrez J, MartínezMeyer E. 2013. An update of high-resolution monthly climate surfaces for Mexico. International Journal of Climatology 34: 2427-2437. DOI: 10.1002/joc.3848

Elith J, Burgman MA, Regan HM. 2002. Mapping epistemic uncertainties and vague concepts in predictions of species distribution. Ecological Modelling 157: 313-329. DOI: 10.1016/S0304-3800(02)00202-8

Elith J, Phillips SJ, Hastie T, Dudík M, Chee YE, Yates CJ. 2011. A statistical explanation of MaxEnt for ecologists. Diversity and Distributions 17: 43-57. DOI: 10.1111/j.1472-4642.2010.00725.x

Frankel O. 1970. Genetic conservation of plants useful to man. Biological Conservation 2: 162-169. DOI: 10.1016/0006-3207(70)90094-7

Freeman EA, Moisen GG. 2008. A comparison of the performance of threshold criteria for binary classification in terms of predicted prevalence and kappa. Ecologial Modelling 217: 48-58. DOI: 10.1016/ j.ecolmodel.2008.05.015

Fryxell PA. 1968. A redefinition of the tribe Gossypieae. Botanical Gazette. 129: 296-308. DOI: 10.1086/336448

Fryxell PA. 1969. The genus Hampea (Malvaceae). Brittonia 21: 359-396. DOI: 10.2307/2805764

Fryxell, PA. 1977. New species of Malvaceae from Mexico and Brazil. Phytologia 37: 285-316. <http:// www.biodiversitylibrary.org/item/48981\#page/10/mode/1up>

Fryxell PA. 1979. The Natural History of the Cotton Tribe. College Station, Texas: Texas A\&M Univ. Press. ISBN-10: 0890960712

Fryxell PA. 1980. A new species of Hampea (Malvaceae) from El Salvador. Systematic Botany. 5: $442-$ 444. DOI: $10.2307 / 2418525$

Fryxell PA. 1988. Malvaceae of Mexico. Systematic Botany Monographs. ISBN-10: 0912861258

González-Abraham C, Ezcurra E, Garcillán PP, Ortega-Rubio A, Kolb M, Creel, JEB. 2015. The human footprint in Mexico: physical geography and historical legacies. PIOS ONE, 10: 1-17, e0121203. DOI: 10.1371/journal.pone.0128055

González-Espinosa M. 1998. Hampea montebellensis. The IUCN Red List of Threatened Species 1998: e.T30760A9576935 DOI: 10.2305/IUCN.UK.1998.RLTS.T30760A9576935.en

Herbario CICY. 2018. Flora de la Península de Yucatán. <http://www.cicy.mx/sitios/flora\%20digital/> (accessed 05 January 15, 2018).

Hernández PA, Graham CH, Master LL, Albert DL. 2006. The effect of sample size and species characteristics on performance of different species distribution modeling methods. Ecography 29: 773-785. DOI: $10.1111 /$ j.0906-7590.2006.04700.x

Howe H, Smallwood J. 1982. Ecology of Seed Dispersal. Annual Review of Ecology and Systematics $\mathbf{1 3}$ 201-228. DOI:10.1146/annurev.es.13.110182.001221

Hu J, Jiang Z. 2010. Predicting the potential distribution of the endangered Przewalski's gazelle. Journal of Zoology 282: 54-63. DOI: 10.1111/j.1469-7998.2010.00715.x

IBM 2011. IBM SPSS Statistics., Version 20.0. Armonk, NY: IBM Corp.

INEGI [Instituto Nacional de Estadística y Geografía]. 2016. Conjunto de datos vectoriales edafológico, escala 1:250000, Serie II. (Continuo nacional). Accessed May 2016

IUCN [International Union for Conservation of Nature]. 2012. IUCN Red List Categories and Criteria: Version 3.1. Gland, Switzerland and Cambridge UK: IUCN. ISBN: 978-2-8317-1435-6

Jones RW. 1994. Systematics and Ecology of the Anthonomus grandis species complex (Coleoptera: Curculionidae) and their Hampea hosts plants (Malvales: Malvaceae). PhD Thesis, Texas A\&M University.

Jones RW. 2001. Evolution of the host plant associations of the Anthonomus grandis species group (Coleoptera: Curculionidae): Phylogenetic tests of various hypotheses. Annals Entomological Society America 94: 51-58 DOI: 10.1603/0013-8746(2001)094[0051:EOTHPA]2.0.CO;2

Jones RW, Baro-Peruyero D. 2002. Reproductive ecology of two species of the Anthonomus grandis Spe- 
cies Group (Coleoptera: Curculionidae) on their Hampea (Malvales: Malvaceae) host plants in Southern Mexico. Environmental Entomology 31: 693-701. DOI: 10.1603/0046-225X-31.4.693

Jones RW, Fryxell PA, Baro D. 1997. Phylogenetic analysis of the genus Hampea (Malvales: Malvaceae). Anales del Instituto de Biología, UNAM, Serie Botánica, 68 :21-42

Royal Botanic Gardens Kew. 2018. Seed Information Database (SID). Version7.1. < http://data.kew.org/ sid/> (accessed March, 2018)

Lodoño-Murcia MC, Sánchez-Cordero V. 2011. Distribución y conservación de especies amenazadas en Mesoamérica, Chocó y Andes tropicales. Revista Mexicana de Biodiversidad. 82: 926-950 DOI: 10.22201/ib.20078706e.2011.3.1214

Marini MA, Cavalcanti RB. 1998. Frugivory by Elaenia flycatchers. Hornero, 15: 47-50

Marmion M, Parviainen M, Luoto M, Heikkinen RK, Thuilier W. 2009. Evaluation of consensus methods in predictive species distribution modelling. Diversity Distribution. 15: 59-69. DOI: 10.1111/j.14724642.2008.00491.x

Marquis RJ, Clark DB. 1989. Habitat and fertilization effects on leaf herbivory in Hampea appendiculata (Malvaceae): Implications for Tropical Firewood systems. Agriculture, Ecosystems \& Environment, 25, 165-174. DOI: 10.1016/0167-8809(89)90048-0

Martínez-Meléndez J, Pérez-Farrera, MÁ, Farrera-Sarmiento O. 2008. Inventario florístico del cerro el Cebú y zonas adyacentes en la Reserva de la Biosfera El Triunfo (polígono V), Chiapas, México. Boletín de la Sociedad Botánica de México, 82: 21-40. DOI: 10.17129/botsci.1779

Maxted N, Kell S, Ford-Lloyd B, Dulloo E, Toledo Á. 2012. Toward the systematic conservation of global crop wild relative diversity. Crop Science 52: 774-785. DOI:10.2135/cropsci2011.08.0415

Meilleur BA, Hodgkin T. 2004. In situ conservation of crop wild relatives: status and trends. Biodiversity and Conservation 13: 663-684. DOI: 10.1023/B:BIOC.0000011719.03230.17

Morales-Ramos JA, Rojas MG, Coleman RJ, King EG. 1998. Potential use of in vitro-reared Catolaccus grandis (Hymenoptera: Pteromalidae) for biological control of the boll weevil (Coleoptera: Curculionidae). Journal of Economic Entomology 91: 101-109 DOI: 10.1093/jee/91.1.101

Pearson RG, Raxworthy CJ, Nakamura M, Townsend Peterson A. 2007. Predicting species distributions from small numbers of occurrence records: a test case using cryptic geckos in Madagascar. Journal of Biogeography 34: 102-117. DOI: 10.1111/j.1365-2699.2006.01594.x

Pérez-Farrera MÁ, Martínez-Camilo R, Martínez-Meléndez N, Farrera-Sarmiento O, Maza-Villalobos S. 2012. Listado florístico del Cerro Quetzal (Polígono III) de la Reserva de la Biosfera El Triunfo, Chiapas, México. Botanical Sciences, 90:, 113-142. DOI: 10.17129/botsci.479

Phillips SJ, Anderson RP, Schapire RE. 2006. Maximum entropy modelling of species geographic distributions. Ecological Modelling 190: 231-259. DOI: 10.1016/j.ecolmodel.2005.03.026

Phillips SJ, Dudik M. 2008. Modeling of species distributions with Maxent: new extensions and a comprehensive evaluation. Ecography, 31: 161-175. DOI: 10.1111/j.2007.0906-7590.05203.x

Ponce-Reyes R, Reynoso-Rosales VH, Watson JE, VanDerWal J, Fuller RA, Pressey RL, Possingham HP. 2012. Vulnerability of cloud forest reserves in Mexico to climate change. Nature, Climate Change 2: 448-452. DOI:10.1038/nclimate1453

Ramírez-Marcial N, González-Espinosa M, Williams-Linera G. 2001. Anthropogenic disturbance and tree diversity in montane rain forests in Chiapas, Mexico. Forest Ecology and Management, 154: 311-326. DOI: $10.1016 / \mathrm{S} 0378-1127(00) 00639-3$

Ramírez-Marcial N, González-Espinosa M, Camacho-Cruz A, Ortiz-Aguilar D. 2010. Forest restoration in Lagunas de Montebello National Park, Chiapas, Mexico. 28: 354-360. DOI:10.3368/er.28.3.354.

Román-Cuesta R. Martínez-Vilalta J. 2006. Effectiveness of protected areas in mitigating fire within their boundaries: case study of Chiapas, Mexico. Conservation Biology, 20: 1074-1086. DOI: 10.1111/ j.1523-1739.2006.00478.x

SEMARNAT [Secretaría del Medio Ambiente y Recursos Naturales]. 2010. Norma Oficial Mexicana NOM-059-SEMARNAT-2010, Protección ambiental - Especies nativas de México de flora y fauna silvestres - Categorías de riesgo y especificaciones para su inclusión, exclusión o cambio - Lista de especies en riesgo._Diario Oficial de la Federación_.2da Sección, 30 de diciembre de 2010.

Stansly PA. 1985. Life history and ecology of the boll weevil on a native host plant in southeastern Mexico. Ph.D. Dissertation, Texas A\&M University, College Station, Texas

Summy KR, Morales-Ramos JA, King EG. 1992. Ecology and potential impact of Catolaccus grandis (Burks) on boll weevil infestations in the lower Rio Grande valley. Southwestern Entomologist 17: 279-288.

Tsoar A, Allouche O, Steinitz O, Rotem D, Kadmon R. 2007. A comparative evaluation of presence-only methods for modelling species distribution. Diversity and Distributions 13: 397-405. DOI: 10.1111/ j.1472-4642.2007.00346.x 